\title{
HUBUNGAN KWALITAS SUMBER DAYA MANUSIA DAN SISTEM INFORMASI TERHADAP PENINGKATAN KINERJA MELALUI PELATIHAN DAN MOTIVASI KERJA PEGAWAI DI LINGKUNGAN PEMERINTAH KOTA BATU
}

\author{
Luqman Almalani \\ DINAS KOMINFO PEMERINTAH KOTA BATU \\ Email : Iuqmanalmalani@yahoo.com
}

\begin{abstract}
Abstrak
Tujuan penelitian ini adalah: untuk menganalisis pengaruh Kwalitas Sumber Daya Manusia dan sistem informasi terhadap peningkatan kinerja melalui pelatihan dan motivasi kerja pegawai di lingkungan pemerintah Kota Batu. Sampel yang digunakan dalam penelitian ini adalah Pegawai di Lingkungan Balaikota Among Kota Batu yang berjumlah 2500 orang dengan metode penyebaran kuisioner. Hasil penelitian ini menunjukkan bahwa 1) Apakah ada hubungan antara kwalitas Sumber Daya Manusia dengan Pelatihan. 2)Apakah ada hubungan antara Pelatihan yang diadakan di Kota Batu dengan motivasi kerja Pegawai di Lingkungan Balaikota Among Tani Kota Batu 3).Apakah ada hubungan antara Motivasi kerja dengan peningkatkan Kinerja 4). Apakah ada hubungan antara Kwalitas Sumber Daya Manusia dengan peningkatan Kinerja di Pemerintahan. 5).Apakah ada hubungan Sistem Informasi yang dikembangkan di Pemerintah Kota Batu dengan peningkatkan Kinerja Pegawai dan 6).Apakah ada hubungan Sistem Informasi dengan Pelatihan.

Kata Kunci: Kwalitas SDM, Sistem Informasi,Peningkatan Kinerja,Pealatihan,dan Motivasi kerja
\end{abstract}

\begin{abstract}
The purpose of this study is to analyze the effect of Quality of Human Resources and information systems on performance improvement through training and motivation of employee work within Batu City government. The sample used in this study were employees in Balai Kota Among Tani Batu City which numbered 2500 people with the method of distributing questionnaires.

The results of this study explore about 1) Relationship between the quality of Human Resources and Training 2) Relationship between the Training held with the Employees work motivation in the Balai Kota Among Tani Batu City Environment. 3). Relationship between work motivation and Performance Improvement. 4). Relationship between the Quality of Human Resources and Performance improvement in Government. 5). Connection to the Information System developed in Batu City Government by increasing Employee Performance and 6). Connection between Information System with Training.

Keywords: HR Quality, Information System, Performance Improvement, Training, and Work Motivation

\section{PENDAHULUAN}

Sumber Daya Manusia merupakan faktor yang menentukan dalam pencapaian tujuan organisasi/lembaga. Sumber daya yang kompeten tentunya dapat melaksanakan visi dan misi sebuah organisasi/lembaga. Berkaitan dengan hal tersebut, maka dalam mencapai suatu tujuannya setiap organisasi/lembaga dipengaruhi perilaku organisasi/lembaga yang
\end{abstract}


merupakan pencerminan dari perilaku dan sikap pelaku yang ada dalam organisasi/lembaga tersebut. Dengan kata lain bahwa keberhasilan suatu organisasi/lembaga sangat tergantung pada Sumber Daya Manusia yang ada dalam organisasi/lembaga tersebut. Artinya semakin tinggi prestasi kerja Sumber Daya Manusia (SDM) yang ada dalam organisasi/lembaga tersebut, tentunya akan membuat organisasi/lembaga itu bisa mencapai tujuannya dengan baik.

Kinerja adalah ukuran dari suatu keberhasilan. Hasil dari suatu pekerjaan dapat berupa barang atau jasa dan kinerja seseorang dapat dilihat dari barang atau jasa yang dihasilkan orang tersebut. Jika barang atau jasa yang dihasilkan orang tersebut sesuai dengan yang diharapkan maka kinerja orang tersebut dikatakan baik. Tetapi jika barang atau jasa yang dihasilkan oleh orang tersebut tidak sesuai dengan yang diharapkan maka dianggap kinerja orang tersebut buruk. (Robbins, 1994:237).

Hasil pelatihan yang ditunjukkan oleh Sumber Daya Manusia yang ada dalam organisasi/Lembaga tersebut juga akan mempengaruhi suatu keberhasilan organisasi/Lembaga tersebut. Pelatihan seseorang juga akan didukung oleh kwalitas Sumber Daya Manusianya.

Sistem Informasi yang sekarang berkembang sangat pesat dapat mendukung peningkatan kinerja Pegawai. Dengan adanya system informasi yang dikembangkan secara tidak langsung akan meningkatkan disiplin pegawai yang ada di lingkungan kerja tersebut baik dari jam kedatangan maupun jam kepulangan, dengan kata lain keberadaan pegawai akan terpantau dengan baik. Sistem informasi juga dapat meningkatkan kesejahteraan pegawai ini di ditunjukkan dengan pegawai melakukan absensi dan mengisi target kinerja disini akan ada reword yang diterima oleh pegawai tersebut.

Pemanfaatan Teknologi Informasi (TI) pada lingkungan pemerintahan menjadi salah satu faktor penting demi menunjang proses berjalannya roda pemerintahan. Teknologi Informasi memberikan banyak keuntungan misalnya penyimpanan, pengiriman, pengaksesan dan pengolahan informasi atau data menjadi semakin cepat.(Kaban, 2009) Namun permasalahannya masih banyak pemanfaatan TI dalam organisasi atau lembaga belum terorganisir dan terkelola dengan baik.(Muthmainnah, 2013) Penerapan tata kelola TI terkait dengan Sistem Informasi Manajemen di lingkungan pemerintahan dapat menunjang berjalannya E-Government dengan baik.

Dari uraian diatas dapat disimpulkan bahwa system informasi merupakan sebuat peralatan dan aplikasi yang dikembangkan oleh suatu organisasi/Lembaga untuk mengukur kinerja dan pelatihan pegawai dengan harapan nantinya dapat meningkatkan kinerja organisasi/Lembaga tersebut.

Sehubungan dengan hal tersebut diatas terdapat hubungan yang erat antara system informasi dengan kinerja perorangan dan kinerja lembaga/organisasi. Dengan kata lain apabila system informasi yang dikembangkan baik akan menunjang Sumber Daya Manusianya baik maka kinerja lembaga atau organisasi juga akan baik pula. 
Sering dengan perkembangan Sistem Informasi maka pemerintah Kota Batu dapat mengukur ketaatan pegawai dan pelayanan lembaga di Lingkungan Balaikota Among Tani Kota Batu dengan baik. Oleh karena itu Pemerintah Kota Batu telah mengembangkan sebuah system informasi berupa absensi secara elektronik berupa finger print, aplikasi SKP online untuk mengukur aktifitas kinerja pegawai. Dengan adanya Sistem Informasi ini Pemerintah Kota Batu mengaharapkan motivasi pegawai akan meningkat serta aktifitas kerja pegawai juga akan meningkat karena dengan adanya system ini segala aktifitas pegawai akan tercatat secara elektronik. Dengan adanya system ini juga maka pimpinan dalam melihat aktifitas pegawai juga akan lebih mudah. Sistem Informasi yang berkembang juga akan meningkatkan kesejahteraan pegawai ini dikarenakan dengan mereka disiplin dalam kehadiran kerja dan aktif dalam mengisi Sasaran Kerja Pegawai (SKP) Online maka secara tidak langsung aka ada nilai point yang didapatkan dan akan menerima Tambahan Penghasilan Pegawai (TPP) setiap bulannya.

Pelatihan - pelatihan terus digalakan untuk meninggatkan SDM yang ada di lingkungan pemerintahan Kota Batu, diharapkan pegawai bisa mengikuti perubahan yang terjadi di Balaikota Among Tani, Karena para pegawai secara tak langsung harus bisa memakai sistem informasi untuk pelaporan kegiatannya sendiri.

Sumber daya manusia mempunyai peranan yang sangat penting dalam interaksinya dengan faktor modal, material, metode, dan mesin. Kompleksitas yang ada dapat menentukan kualitas manusia, oleh karena itu mengharuskan kita untuk selalu berhati-hati dan memperhatikan setiap aspeknya. Oleh karena itu, budaya organisasi merupakan bagian penting dalam memahami organisasi seluruhnya. Budaya menjadi elemen penting yang mendukung terciptanya sebuah strategi yang dapat meningkatkan motivasi kerja yang pada akhirnya akan meningkatkan kinerja organisasi karena budaya organisasi merupakan fenomena yang saling bergantung.

Oleh karena itu begitu pentingnya kwalitas Sumber Daya Manusia dan Sistem Informasi berbasis kinerja yang ada pada Pemerintahan Kota Batu akan sangat menentukan keberhasilan pembangunan yang telah dicanangkan oleh Pemerintah Kota Batu melalui program dan kegiatan yang telah ditetapkan dalam tiap tahunnya.

Dari uraian diatas berkeinginan untuk mengadakan penelitian tentang kwalitas Sumber Daya Manusia serta Sistem Informasi yang dikembangkan di Lingkungan Balaikota Among Tani Kota Batu dalam rangka meningkatkan kinerja pegawai di lingkungan pemerintahan Kota Batu. Dalam hal ini akan mengadakan penelitian pada Pegawai di Lingkungan Pemerintahan Kota Batu dengan judul :" Hubungan Kwalitas Sumber Daya Manusia Dan Sistem Informasi Terhadap Peningkatan Kinerja Melalui Pelatihan dan Motivasi Kerja Pegawai di Lingkungan Pemerintah Kota Batu"

\section{KAJIAN TEORI}

\section{Teori Tentang Kwalitas Sumber Daya Manusia}

Kualitas sumberdaya manusia adalah kemampuan sumberdaya manusia untuk melaksanakan tugas dan tanggung jawab yang diberikan 
kepadanya dengan bekal pendidikan, pelatihan, dan pengalaman yang cukup memadai (Widodo, 2001 dalam Arfianti, 2011). Menurut Tjiptoherijanto (2001) dalam Alimbudiono \& Fidelis (2004), untuk menilai kapasitas dan kualitas sumber daya manusia dalam melaksanakan suatu fungsi, termasuk akuntansi, dapat dilihat dari level of responsibility dan kompetensi sumberdaya tersebut. Tanggung jawab dapat dilihat dari atau tertuang dalam deskripsi jabatan. Deskripsi jabatan merupakan dasar untuk melaksanakan tugas dengan baik. Tanpa adanya deskripsi jabatan yang jelas, sumberdaya tersebut tidak dapat melaksanakan tugasnya dengan baik. Sedangkan kompetensi dapat dilihat dari latar belakang pendidikan, pelatihan-pelatihan yang pernah diikuti, dan dari keterampilan yang dinyatakan dalam pelaksanaan tugas.

Pengertian Sumber Daya Manusia dikemukakan pula oleh Sedarmayanti (2001) dalam buku "Sumber Daya manusia dan produktivitas Kerja" bahwa "sumber Daya Manusia adalah tenaga kerja atau pegawai di dalam suatu organisasi yang mempunyai peran penting dalam mencapai keberhasilan".

Pengertian lain dikemukakan oleh Nawawi (1997) dalam buku "Manajemen Sumber Daya Manusia Untuk Bisnis Kompetitif", adalah sebagai berikut : "Sumber daya manusia adalah manusia yang bekerja di suatu organisasi (disebut juga personal tenaga kerja, atau karyawan)".

Salim (1996:35) dalam bukunya "Aspek Sikap Mental dalam Manajemen sumber Daya Manusia" mengemukakan pengertian Kualitas Sumber Daya Manusia sebagai berikut: Kualitas Sumber Daya Manusia adalah nilai dari perilaku seseorang dalam mempertanggungjawabkan semua perbuatannya baik dalam kehidupan pribadi maupun kehidupan bermasyarakat dan berbangsa.

Sedangkan Menurut Ndraha (1997) dalam bukunya "Pengantar Teori Pengembangan Sumber Daya Manusia" mengatakan bahwa pengertian kualitas sumber daya manusia, yaitu: Sumber Daya Manusia yang berkualitas adalah sumber daya manusia yang mampu menciptakan bukan saja nilai komparatif, tetapi juga nilai kompetitif - generatif - inovatif dengan menggunakan energi tertinggi seperti intelligence, creativity, dan imagination, tidak lagi semata-mata menggunakan energi kasar seperti bahan mentah, lahan, air, energi otot, dan sebagainya.

Sebagai bahan perbandingan, penulis juga mengemukakan pengertian kualitas sumber daya manusia menurut Matindas (1997) dalam bukunya "Kualitas Sumber Daya Manusia", sebagai berikut: Kualitas Sumber Daya manusia adalah sumber daya manusia yang bukan hanya memiliki kesanggupan untuk menyelesaikan pekerjaannya, melainkan juga untuk mengembangkan dirinya serta mendorong pengembangan diri rekanrekannya.

Pengertian Kualitas Sumber Daya Manusia menurut Danim (1996) dalam bukunya "Transformasi Sumber Daya Manusia", sebagai berikut: Kualitas Sumber Daya Manusia adalah sumber daya yang memenuhi kriteria kualitas fisik dan kesehatan, kualitas intelektual (pengetahuan dan keterampilan), dan kualitas mental spiritual (kejuangan). 
Menurut Hasibuan (2013:40), rekrutmen adalah: Serangkaian aktivitas mencari dan memikat pelamar kerja dengan motivasi, kemampuan, keahlian, dan pengetahuan yang di perlukan untuk menutupi kekuarangan yang di identifikasi dalam perencanaan kepegawaian. Berdasarkan kutipan tersebut dapat disimpulkan bahwa rekrutmen adalah usaha mencari, menemukan, menarik dan mempengaruhi tenaga kerja agar melamar lowongan pekerjaan yang ada dalam suatu perusahaan.

\section{Teknologi Informasi}

Teknologi informasi dapat diartikan sebagai suatu teknologi yang digunakan untuk mengolah data, termasuk memproses, mendapatkan, menyusun, menyimpan, memanipulasi data dalam berbagai cara untuk menghasilkan informasi yang berkualitas, yaitu informasi yang relevan, akurat dan tepat waktu, yang digunakan untuk keperluan pribadi, bisnis, dan pemerintahan dan merupakan informasi yang strategis untuk pengambilan keputusan. Teknologi ini menggunakan seperangkat komputer untuk mengolah data, sistem jaringan untuk menghubungkan satu komputer dengan komputer yang lainnya sesuai dengan kebutuhan, dan teknologi telekomunikasi digunakan agar data dapat disebar dan diakses secara global.

Komputer sebagai salah satu komponen dari teknologi informasi merupakan alat yang bisa melipatgandakan kemampuan yang dimiliki manusia dan komputer juga bisa mengerjakan sesuatu yang manusia mungkin tidak mampu melakukannya. Pengolahan data menjadi suatu informasi dengan bantuan komputer jelas akan lebih meningkatkan nilai dari nilai informasi yang dihasilkan.

Peningkatan nilai informasi tersebut seperti berikut: Informasi yang memiliki nilai tinggi adalah informasi yang disajikan dalam waktu yang cepat dan tepat. Untuk pemrosesan data manual biasanya berlaku bahwa semakin cepat waktu yang diinginkan untuk pemrosesan, maka biaya yang dibutuhkan akan semakin besar. Dengan bantuan komputer pengolahan data bisa diatur sedemikian rupa sehingga informasi dapat disajikan tepat waktu dan dengan biaya yang masih di bawah manfaat itu sendiri. Dengan kata lain, kita bisa mengatur pengolahan data sehingga manfaat ekonomis sebuah informasi dapat diperoleh secara maksimal (Wahana Komputer, 2003).

Teknologi informasi meliputi komputer (mainframe, mini, micro), perangkat lunak (software), database, jaringan (internet, intranet), electronic commerce, dan jenis lainnya yang berhubungan dengan teknologi (Wilkinson et al., 2000). Teknologi informasi terdiri dari bagian utama yaitu teknologi komputer dan perlengkapan komputer yang berfungsi untuk menerima data, menyimpan data dan mengolah data menjadi informasi, serta mencetak atau membuat dan mengkomunikasikan informasi tersebut. Sistem informasi yang menggunakan teknologi dengan cara dan alat manual dan mekanik disebut sistem informasi manual, sedangkan sistem informasi yang didominasi oleh alat elektronik disebut sistem informasi elektronik. Sistem informasi elektronik yang menggunakan komputer disebut sistem informasi berbasis komputer. 
Pemanfaatan teknologi informasi tersebut mencakup adanya (a) pengolahan data, pengolahan informasi, sistem manajemen dan proses kerja secara elektronik dan (b) pemanfaatan kemajuan teknologi informasi agar pelayanan publik dapat diakses secara mudah dan murah oleh masyarakat di seluruh wilayah negeri ini (Hamzah, 2009).

Pengertian Hand Geometry (Geometri Tangan) Salah satu sistem biometrik yang dimiliki manusia adalah geometri tangan. Geometri tangan adalah struktur geometri tangan seseorang, seperti lebar jari tangan, lebar telapak tangan, panjang jari tangan, tebal telapak tangan dan suhu tangan (Lim, 2004 dalam Satriyanto). Sistem identifikasi berbasis geometri tangan telah banyak digunakan. Selain tekniknya relatif mudah untuk digunakan, faktor faktor seperti cuaca atau kulit kering tidak mempengaruhi ketelitian identifikasi. Hand Geometry adalah salah satu metoda pembuktian dan biasanya menawarkan kinerja, mudah digunakan, dan perhitungan yang baik (Alamsyah, 2003). Hand Geometry secara luas digunakan untuk kendali akses fisik dan sistem waktu atau kehadiran.

Keunggulan Hand Geometry Dalam upaya mencapai efisiensi kerja, faktor kehadiran (absensi) karyawan merupakan hal yang cukup penting, apalagi berhubungan dengan produksi, penggajian, prestasi kerja, dan lainlain. Pada alat pencatatan absensi karyawan yang konvensional banyak memerlukan intervensi pegawai bagian administrasi kepegawaian (SDM atau Human Resources Management) maupun kejujuran karyawan. Hal ini dikarenakan adanya manipulasi data kehadiran apabila proses ini tidak dilakukan pengawasan secara kontinyu. Dengan sistem absensi berbasis biometrik proses pengambilan informasi kehadiran karyawan menjadi hampir $100 \%$ akurat karena didasarkan sidik jari masing-masing serta proses pencatatan dan pelaporannya menjadi otomatis oleh software. Kesalahan maupun manipulasi catatan dapat dihilangkan karena intervensi pegawai administrasi menjadi minimal. Informasi yang akurat merefleksikan kondisi yang sebenarnya menjadi landasan untuk pengambilan keputusan serta kebijakan untuk kemajuan suatu instansi atau lembaga. Kelemahan sistem konvensional adalah terbukanya peluang manipulasi, kesalahan pencatatan, maupun hilangnya catatan kehadiran seorang karyawan. Juga, terbuka kemungkinan terjadinya buddy punching. dimana rekan sekerja yang lain mencatatkan waktu kerja yang bukan dirinya. Hal ini membuat pencatatan waktu kehadiran karyawan menjadi tidak akurat.

Integrasi ke sistem kepegawaian membutuhkan analisis dan perancangan software yang terpadu, dengan sistem konvensional cukup sulit untuk diotomatisasikan karena pencatatan informasi kehadiran secara manual. Pencatatan menggunakan komputer seperti pada penggunaan geometrik tangan ini sangat memungkinkan keterpaduan dengan sistem kepegawaian serta pengembangan sistem lebih lanjut. Sistem pencatatan kehadiran berbasis biomatriks (Hand Geometry) mampu menjawab permasalahan absensi diatas

\section{Pelatihan}

Menurut Hamalik (2007: 10), pelatihan adalah suatu proses yang meliputi serangkaian tindak (upaya) yang dilaksanakan dengan sengaja dalam bentuk pemberian bantuan kepada tenaga kerja yang dilakukan oleh 
tenaga profesional kepelatihan dalam satuan waktu yang bertujuan untuk meningkatkan kemampuan kerja peserta dalam bidang pekerjaan tertentu guna meningkatkan efektivitas dan produktivitas dalam suatu organisasi.

Menurut Sikula dalam Mangkunegara (2009: 44) Training is shortterm educational process utilizing a systematic and organized procedure by wich non-managerial personal learn technical knowledge and skills for a definite purpose. (Pelatihan adalah suatu proses pendidikan jangka pendek yang mempergunakan prosedur sistematis dan terorganisir dimana pegawai managerial mempelajari pengetahuan konseptual dan keterampilan teknis dalam tujuan terbatas.

Pelatihan adalah suatu proses dimana orang-orang mencapai kemampuan tertentu untuk membantu mencapai tujuan organisasi. Oleh karena itu, proses ini terikat dengan berbagai tujuan organisasi, pelatihan dapat dipandang secara sempit maupun luas. Secara terbatas, pelatihan menyediakan para pegawai dengan pengetahuan yang spesifik dan dapat diketahui serta keterampilan yang digunakan dalam pekerjaan mereka saat ini (Mathis, 2002: 5). Berdasarkan beberapa pengertian di atas, penulis dapat menarik kesimpulan bahwa pelatihan adalah suatu proses pendidikan yang menggunakan prosedur sistematis dengan memberikan pengetahuan untuk meningkatkan kemampuan kerja peserta dalam bidang pekerjaan tertentu untuk membantu mencapai tujuan organisasi.

\section{Pengertian Motivasi}

Istilah Motivasi dalam kehidupan sehari hari memiliki pengertian yang beragam baik yang berhubungan dengan perilaku individu maupun perilaku organisasi. Namun apapun pengertian motivasi merupakan unsure yang penting dalam diri manusia. Dasar utama pelaksanaan motivasi oleh seorang pemimpin adalah pengetahuan dan perhatian terhadap perilaku manusia yang dipimpinnya sebagai suatu factor penentu keberhasilan organisasi.

Motivasi menutut Hasibuan (2001 :219) adalah pemberian daya penggerak yang menciptakan kegairahan kerja seseorang, agar mau bekerjasama, bekerja efektif dan terintegrasi dengan segala daya untuk mencapai kepuasan.

Pengertian motivasi menurut handoko (1992:9) motivasi adalah suatu tenaga atau factor yang terdapat dalam diri manusia yang menimbulkan, mengarahkan dan mengorganisasikan tingkah lakunya.

Beberapa pengertian motivasi yang dikemukanan oleh ahli tersebut dapat diyatakan motivasi kerja terbentuk dari adanya kebutuhan, sikap (Attitutude) yang mendorong karyawan agar lebih bersemangat dan bergairah dalam menghadapi situasi kerja diperusahaan.

\section{Pengertian Kinerja}

Menurut, Widodo (2005: 78) kinerja adalah merupakan suatu kegiatan dan menyempurnakannya sesuai dengan tanggung jawabnya dengan hasil seperti yang diharapkan. Sementara itu, kinerja sebagai kata benda mengandung arti "Thing Done" (suatu hasil yang telah dikerjakan).

Sedangkan Sudarto (1999: 3) mengungkapkan, bahwa Kinerja merupakan sebagai hasil atau unjuk kerja dari suatu organisasi yang dilakukan oleh individu yang dapat ditunjukkan secara konkret dan dapat di 
ukur. Kinerja individu perorangan (individual performance) dan organisasi (organizational performance) memiliki keterkaitan yang sangat erat. Tercapainya tujuan organisasi tidak bisa dilepaskan dari sumber daya yang dimiliki oleh organisasi yang digerakkan atau dijalankan oleh kelompok orang yang berperan aktif sebagai pelaku dalam upaya mencapai tujuan organisasi tersebut. Sementara itu, individu atau sekelompok orang sebagai pelaksana dalam menjalankan tugas, wewenang dan tanggung jawab dengan baik, sangat tergantung kepada struktur (manajemen dan teknologi) dan sumber daya lain, seperti keuangan dan peralatan yang dimiliki oleh organisasi. Dengan demikian, kinerja lembaga (organisasi) salah satunya ditentukan oleh kinerja sekelompok orang sebagai pelaku organisasi. Salah satu kinerja aparat dapat diartikan sebagai suatu bentuk ukuran efisiensi dan efektivitas tidaknya suatu organisasi dijalankan.

Sedangkan menurut Handoko (1986: 7) mengungkapkan untuk mengukur kinerja (performance) seseorang ada dua konsepsi utama yaitu efisiensi dan efektivitas. Efisiensi adalah kemampuan untuk menyelesaikan suatu pekerjaan dengan benar. Efisiensi ini merupakan konsep matematis atau merupakan perhitungan rasional keluaran yang lebih tinggi (hasil, produktivitas, performance) disbanding masukan-masukan (tenaga kerja, bahan, uang, mesin, dan waktu). Dengan kata lain dapat memaksimumkan keluaran dengan masukan terbatas. Sedangkan efektivitas adalah kemampuan untuk memilih tujuan yang tepat atau peralatan yang tepat untuk mencapai tujuan yang telah ditetapkan. Seorang karyawan yang efektif adalah seorang yang dapat memilih pekerjaan yang dapat dilakukan atau metode (cara) yang tepat untuk mencapai tujuan.

Dari berbagai pernyataan tentang kinerja tersebut, dapat disimpulkan bahwa kinerja adalah Perbuatan, Penampilan, Prestasi, daya guna dan untuk kerja dari suatu organisasi atau individu yang dapat ditunjukkan secara nyata dan dapat diukur. Bertitik tolak dari kata kinerja di atas maka dapat kita bahas tentang pengertian kinerja aparat di mana kinerja aparat tidak lain dari hasil kerja pegawai aparat, pengertian aparat itu sendiri dalam kamus besar bahasa Indonesia adalah orang yang bekerja pada pemerintahan.

\section{Kerangka Konseptual}

Dari hasil penelitian terdahulu dan kajian teori yang telah diterangkan diatas maka dalam penelitian ini dapat digambarkan sebagai berikut:

\section{Gambar. 2.1. Kerangka Konseptual}

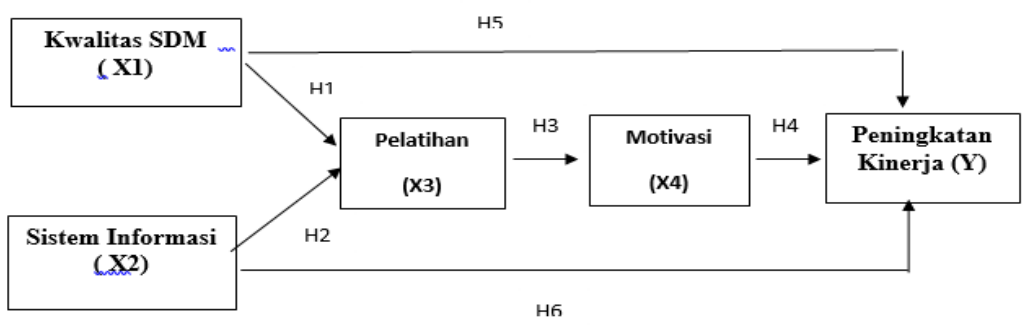


Berdasarkan kerangka konseptual yang ada pada gambar 2.1. dapat dirumuskan hipotesis sebagai berikut:

a. $\mathrm{H1}$ : Kwalitas SDM berpengaruh terhadap pelatihan pegawai.

b. $\mathrm{H} 2$; Sistem Informasi berpengaruh terhadap hasil Pelatihan yang di ikuti pegawai.

c. H3 : Pelatihan berpengaruh terhadap motivasi.

d. H4 : Motivasi berpengaruh terhadap peningkatan kinerja.

e. H5 : Kwalitas SDM berpengaruh terhadap peningkatan kinerja pegawai.

f. H6 : Sistem Informasi berpengaruh terhadap peningkatan kinerja

\section{METODE PENELITIAN}

Penelitian ini menggunakan metode survey dengan mengambil sampel dari populasi dan menggunakan kuisioner sebagai alat pengumpul data yang utama. Sehingga jenis penelitian yang digunakan adalah Kuantitatif. Lokasi penelitian adalah tempat sumber data yang dianggap sebagai suatu populasi sehingga dapat diambil subyek yang diteliti. Penelitian ini dilaksanakan pada pegawai dilingkungan Balaikota Among Tani Kota Batu. Waktu penelitian dilaksanakan dalam kurun waktu bulan Oktober - Desember 2018

Untuk sampel dari populasi Organisasi Perangkat Daerah di Lingkungan Pemerintah Kota Batu dan masing masing OPD sebanyak 5 orang dimulai dari staf sampai pejabat eslon 4,3, dan 2 sehingga total responden sekitar 200 orang pegawai dari sekitar 2500 pegawai yang ada di Lingkungan Pemerintah Kota Batu kecuali Guru dan Tenaga Kesehatan mengingat mereka berada di luar Balaikota Among Tani. Metode yang digunakan dalam penelitian ini adalah dengan menggunakan Analisis Structural Equation Modeling (SEM)

\section{HASIL ANALSIS DATA Uji Reliabilitas}

Reabilitas menunjukkan pada suatu pengertian bahwa suatu intrumen dapat dipercaya untuk dapat digunakan sebagai alat pengumpul data karena instrument tersebut sudah baik. Dengan demikian reliabilitas menunjuk pada tingkat keterhandalan suatu instrument (Arikunto, 2002 :154)

Rumus yang digunakan untuk menghitung reliabilitas dalam penelitian ini adalah menggunakan rumus alpha cronbach. Berdasrkan rumus tersebut, suatu instrument dapat dikatakan handal atau reliable apabila memiliki nilai koefisien kehandalan lebih dari atau sama dengan 0.5

Tabel 4.5.

Uji Reliabilitas

\begin{tabular}{|c|c|c|c|}
\hline No & Variabel & $\begin{array}{c}\text { Koefisien } \\
\text { Alpha }\end{array}$ & Keterangan \\
\hline 1. & $\left(X_{1}\right)$ & 0.827 & Reliabel \\
\hline 2. & $\left(X_{2}\right)$ & 0.808 & Reliabel \\
\hline
\end{tabular}




\begin{tabular}{|c|c|c|c|}
\hline 3. & $\left(X_{3}\right)$ & 0.717 & Reliabel \\
\hline 4. & $\left(X_{4}\right)$ & 0.720 & Reliabel \\
\hline 5. & $\mathrm{Y}$ & 0.625 & Reliabel \\
\hline
\end{tabular}

Sumber: Data Primer diolah (Desember.2018)

bedasarkan tabel 4.4. hasil uji reliabilitas menunjukkan bahwa seluruh item variabel yang digunakan adalah reliable, yaitu dimana untuk masing masing item variabel mempunyai nilai $r$ Alpha lebih dari 0,500 kecuali variable $Y$ dengan nilai alfa 0,312, artinya bahwa alat ukur ini mampu menghasilkan data yang dapat dipercaya.

\section{Analisis Structural Equational Modelling (SEM) Uji Asumsi SEM}

Sesuai dengan kajian pustaka dan tujuan penelitian maka dapat dikembangkan model struktur sebagai berikut:

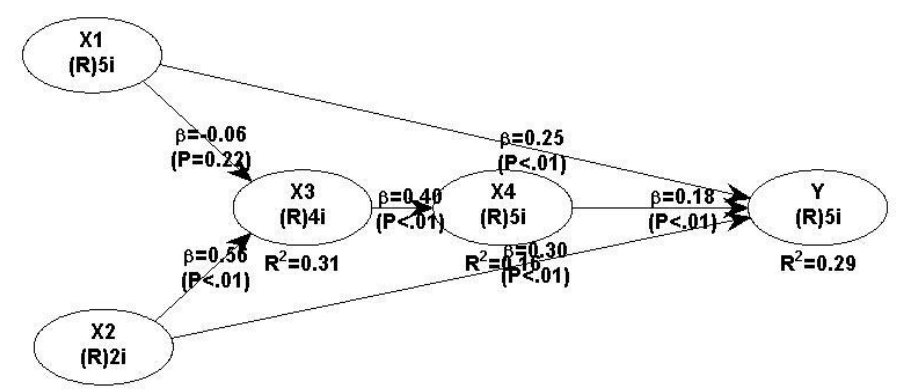

Dari gambar diatas menunjukkan bahwa terjadi pengaruh yang signifikan antara Kwalitas SDM (X1) terhadap peningkatan kinerta (Y) yang ditunjukkan dengan koefisien 0,25 dengan $\mathrm{p}<0,01$, akan tetapi antara Kwalitas SDM (X1) terhadap Pelatihan (X3) kurang signifikan ini ditunjukkan dengan koefisien 0,06 dengan $p=0,22$, sedang Teknologi Informasi (X2) terhadap pelatihan (X3) terjadi pengaruh yang signifikan ditunjukkan dengan koefisien 0,56 dengan $p<0,01$, begitu antara teknologi informasi (X2) terhadap Kinerja pegawai $(Y)$ juga terjadi pengaruh yang signifikan ini ditunjukan dengan koefisien 0,30 dengan nilai $p<0,01$, sedangkan pengaruh pelatihan (X3) terhadap motivasi kerja (X4) terjadi pengaruh yang signifikan ini ditunjukkan dengan koefisien 0,40 dengan $p<0,01$. Dan pengaruh mottivasi kerja (X4) terhadap kinerja pegawai $(\mathrm{Y})$ terjadi pengaruh yang signifikan ini ditunjukkan dengan koefisien 0,18 dengan $p<0,01$. Dari hasil gambar ful model struktur diatas indikator dikatakan signifikan jika nilai koefisien $>0,29$ dengan $p$ value $<0,01$. 
Tabel 4.10.

Pengujian Goodness Of Fit Ful Model Struktural

\begin{tabular}{|c|c|c|c|c|}
\hline No & Godness Of Fit Indeks & Kriteria Fit & Hasil Model & Ket. \\
\hline 1 & $\begin{array}{l}\text { Average path coefficient } \\
\text { (APC) }\end{array}$ & $\mathrm{p}<0.05$ & $0.292, p<0,001$ & Baik \\
\hline 2 & Average R-squared (ARS) & $p<0.05$ & $0.251, P<0.001$ & Baik \\
\hline 3 & $\begin{array}{l}\text { Average adjusted R-squared } \\
\text { (AARS) }\end{array}$ & $p<0.05$ & $0.242, P<0.001$ & Baik \\
\hline 4 & Average block VIF(AVIF) & $\begin{array}{l}\text { Acceptable if }<=5 \text {, } \\
\text { ideally }<=3.3\end{array}$ & $\begin{array}{l}1.121, \text { acceptable if }<= \\
5, \text { ideally }<=3.3\end{array}$ & Baik \\
\hline 5 & $\begin{array}{l}\text { Average Full collinearity VIF } \\
\text { (AFVIF) }\end{array}$ & $\begin{array}{l}\text { Acceptable if }<=5, \\
\text { ideally }<=3.3\end{array}$ & $\begin{array}{l}1.414, \text { acceptable if }<= \\
5, \text { ideally }<=3.3\end{array}$ & Baik \\
\hline 6 & Tenenhaus Gof (GOF) & $\begin{array}{l}\text { Small }>=0.1, \text { medium } \\
>=0.25, \text { large }>=0.36\end{array}$ & $\begin{array}{l}0.368, \text { small }>=0.1 \\
\text { medium }>=0.25, \text { large } \\
>=0.36\end{array}$ & Baik \\
\hline 7 & $\begin{array}{l}\text { Sympson's paradox ratio } \\
\text { (RSCR) }\end{array}$ & $\begin{array}{l}\text { Acceptable if }>=0.7 \text {, } \\
\text { ideally }=1\end{array}$ & $\begin{array}{l}0.833, \text { acceptable if }>= \\
0.7, \text { ideally }=1\end{array}$ & Baik \\
\hline 8 & $\begin{array}{l}\text { R-squared contribution ratio } \\
\text { (RSCR) }\end{array}$ & $\begin{array}{l}\text { Acceptable if }>=0.9 \text {, } \\
\text { ideally }=1\end{array}$ & $\begin{array}{l}0.987, \text { acceptable if }>= \\
0.9, \text { ideally }=1\end{array}$ & Baik \\
\hline 9 & $\begin{array}{l}\text { Statistical suppression ratio } \\
\text { (SSR) }\end{array}$ & Acceptable if $>=0.7$ & $\begin{array}{l}1.000, \text { acceptable if }>= \\
0.7\end{array}$ & Baik \\
\hline 10 & $\begin{array}{l}\text { Nonlinear bivariate causality } \\
\text { direction ratio (NLBCDR) }\end{array}$ & Acceptable if $>=0.7$ & $\begin{array}{l}0.750 \text {, acceptable if }>= \\
0.7\end{array}$ & Baik \\
\hline
\end{tabular}

Sumber Data Primer diolah ( Desember 2018)

Berdasarkan tabel diatas dapat dijelaskan bahwa pengujian Godness Of Fit Ful Model Struktur semua hasil model pengujian telah sesuai dengan yang telah di tetapkan dalam kriteria Fit atau dengan hasil baik seperti Average path coefficient (APP), Average R-squared (ARS), Average adjusted R-squared (AARS), Average block VIF(AVIF), Average Full collinearity VIF (AFVIF), Tenenhaus Gof (GOF), Sympson's paradox ratio (RSCR), R-squared contribution ratio (RSCR), Statistical suppression ratio (SSR), Nonlinear bivariate causality direction ratio (NLBCDR) baik.

Berdasarkan tabel diatas dapat diketahui bahwa kriteria- kriteria dalam uji goodness of fit untuk model struktur diatas secara umum sudah memenuhi kriteria yang dianjurkan atau hasilnya sudah sesuai dengan indeks yang ada.

Tabel 4.11

Output Combined Loadings and Cross -Loadings

\begin{tabular}{|l|l|l|l|l|l|l|l|l|}
\hline & X1 & X2 & X3 & X4 & $Y$ & $\begin{array}{l}\text { (type As } \\
\text { Defined) }\end{array}$ & SE & P value \\
\hline X1.1 & $(0.835)$ & -0.163 & 0.092 & -0.051 & 0.140 & Reflective & 0.063 & $<0.001$ \\
\hline X1.2 & $(0.749)$ & 0.299 & -0.175 & -0.029 & 0.134 & Reflective & 0.064 & $<0.001$ \\
\hline X1.3 & $(0.859)$ & 0.096 & -0.059 & 0.055 & 0.080 & Reflective & 0.063 & $<0.001$ \\
\hline X1.4 & $(0.746)$ & -0.154 & 0.120 & -0.016 & -0.349 & Reflective & 0.064 & $<0.001$ \\
\hline X1.5 & $(0.180)$ & -0.305 & 0.085 & 0.163 & -0.145 & Reflective & 0.072 & 0.007 \\
\hline
\end{tabular}


Pascasarjana Universitas Islam Malang

\begin{tabular}{|l|l|l|l|l|l|l|l|l|}
\cline { 7 - 8 } X2.1 & 0.086 & $(0.829)$ & 0.237 & -0.052 & 0.106 & Reflective & 0.063 & $<0.001$ \\
\hline X2.2 & -0.086 & $(0.829)$ & -0.237 & 0.052 & -0.106 & Reflective & 0.063 & $<0.001$ \\
\hline X3.1 & 0.111 & 0.208 & $(0.828)$ & 0.034 & 0.089 & Reflective & 0.063 & $<0.001$ \\
\hline X3.2 & 0.090 & 0.142 & $(0.642)$ & 0.124 & 0.243 & Reflective & 0.066 & $<0.001$ \\
\hline X3.3 & -0.070 & -0.158 & $(0.883)$ & -0.112 & -0.041 & Reflective & 0.063 & $<0.001$ \\
\hline X3.4 & -0.127 & -0.179 & $(0.692)$ & -0.013 & -0.279 & Reflective & 0.065 & $<0.001$ \\
\hline X4.1 & -0.059 & 0.235 & 0.486 & $(0.457)$ & -0.285 & Reflective & 0.068 & $<0.001$ \\
\hline X4.2 & 0.069 & -0.308 & -0.065 & $(0.785)$ & 0.270 & Reflective & 0.064 & $<0.001$ \\
\hline X4.3 & 0.074 & -0.082 & -0.013 & $(0.830)$ & -0.146 & Reflective & 0.063 & $<0.001$ \\
\hline X4.4 & -0.058 & 0.191 & -0.387 & $(0.718)$ & 0.256 & Reflective & 0.065 & $<0.001$ \\
\hline X4.5 & -0.060 & 0.083 & 0.148 & $(0.789)$ & -0.183 & Reflective & 0.064 & $<0.001$ \\
\hline Y1 & 0.191 & -0.250 & -0.078 & -0.042 & $(0.752)$ & Reflective & 0.064 & $<0.001$ \\
\hline Y2 & 0.016 & 0.615 & -0.417 & -0.335 & $(0.628)$ & Reflective & 0.066 & $<0.001$ \\
\hline Y3 & -0.115 & -0.287 & 0.082 & 0.138 & $(0.747)$ & Reflective & 0.064 & $<0.001$ \\
\hline Y4 & -0.096 & 0.052 & 0.432 & 0.192 & $(0.616)$ & Reflective & 0.066 & $<0.001$ \\
\hline Y5 & -0.074 & -0.134 & -0.065 & 0.169 & $(0.119)$ & Reflective & 0.073 & 0.052 \\
\hline
\end{tabular}

Notes: Loadings are unrotated and cross-loadings are oblique-rotated. SEs and $P$ values are for loadings. $P$ values $<0.05$ ar

Sumber: Data Primer di olah(Desember 2018)

\section{PEMBAHASAN}

Dari table diatas dapat dilihat bahwa hampir semua indikator dengan p-value $<0,001$ atau bisa dikatakan signifikan dikarenakan p-value lebih kecil dari <0,05, akan tetapi ada 2 indikator yang masih melebihi dari 0,05 yaitu indicator $X 1.5$ dengan nilai $p$ value 0,007 dan indikator $Y 5$ dengan $p$ value 0,052 . Dan dari table diatas juga tampak bahwa indikator X1.1 sampai dengan X1.5 mempunyai lodings yang lebih besar ke konstruk X1 sebesar rata rata 0,67 dan cross loadings ke konstruk $X 2, X 3 \quad X 4$ dan $Y$ lebih rendah dari $\mathrm{X} 1$. Hasil cross loadings ini juga dapat menjadi indikasi terpenuhinya kriteria validitas diskriminan, Sedangkan indikator X2.1 sampai dengan X2.2 mempunyai loading yang lebih besar ke konstruk X2 sebesar rata rata 0,82 dan cross loadings ke konstruk $\mathrm{X} 1, \mathrm{X} 3, \mathrm{X} 4$ dan $\mathrm{Y}$ lebih rendah dari $\mathrm{X} 2$. Hasil cross loadings ini juga dapat menjadi indikasi terpenuhinya kriteria validitas diskriminan. Sedangkan indikator X3.1 sampai dengan X3.4 mempunyai loading yang lebih besar ke konstruk X3 sebesar rata rata 0,76 dan cross loadings ke konstruk X1, X2,X4 dan Y lebih rendah dari $X 3$. Hasil cross loadings ini juga dapat menjadi indikasi terpenuhinya kriteria validitas diskriminan. Sedangkan indikator X4.1 sampai dengan X4.5 mempunyai loading yang lebih besar ke konstruk X4 sebesar rata rata 0,72 dan cross loadings ke konstruk X1, X2,X3 dan Y lebih rendah dari $X 3$. Hasil cross loadings ini juga dapat menjadi indikasi 
terpenuhinya kriteria validitas diskriminan. Sedangkan indikator Y1 sampai dengan $Y 5$ mempunyai loading yang lebih besar ke konstruk $Y$ sebesar rata rata 0,57 dan cross loadings ke konstruk $\mathrm{X} 1, \mathrm{X} 2, \mathrm{X} 3$ dan $\mathrm{X} 4$ lebih rendah dari $Y$ yaitu rata rata 0,57 , akan tetapi ada 1 indikator $Y 5$ yang mempunyai kontruks lebih besar ke $\mathrm{X} 4$ dengan rata rata 0,11 . Hasil cross loadings ini juga dapat menjadi indikasi terpenuhinya kriteria validitas diskriminan.

\section{SIMPULAN DAN SARAN}

Berdasarkan hasil penelitian dan pembahasan mengenai hubungan Kwalitas Sumber Daya Manusia dan sistem informasi terhadap peningkatan kinerja melalui pelatihan dan motivasi kerja pegawai di Lingkungan Pemerintah Kota Batu, maka dapat ditarik simpulan sebagai berikut:

a. Kurang adanya pengaruh antara kwalitas SDM terhadap pelatihan bagi pegawai yang ada di lingkungan pemerintah Kota Batu mungkin di sebabkan karena faktor - faktor lain yang ada di luar indikator yang sudah ditentukan oleh peneliti.

b. Terdapat pengaruh antara teknologi informasi terhadap pelatihan pegawai yang ada di lingkungan pemerintah Kota Batu.

c. Terdapat pengaruh antara pelatihan terhadap motivasi kerja pegawai yang ada di lingkungan pemerintah Kota Batu.

d. Terdapat pengaruh antara motivasi kerja pegawai terhadap peningkatan kinerja pegawai yang ada di lingkungan pemerintah Kota Batu.

e. Terdapat pengaruh antara kwalitas SDM yang dimiliki oleh pegawai di lingkungan pemerintah Kota Batu serta teknologi informasi terhadap peningkatan kinerja pegawai yang ada di Kota Batu.

Berdasarkan hasil penelitian yang telah disimpulkan tersebut diatas, maka dapat disampaikan beberapa saran sebagai berikut:

a. Kwalitas SDM yang ada di lingkungan pemerintah Kota Batu perlu ditingkatkan dengan jalan pelatihan - pelatihan terutama dalam penggunaan teknologi informasi.

b. Teknologi informasi yang dikembangkan di lingkungan pemerintah Kota Batu harus dapat mempengaruhi motivasi kerja bagi pegawai yang ada.

c. Dengan adanya teknologi informasi di harapkan dapat memantau kinerja pegawai yang ada di lingkungan pemerintah Kota Batu baik dari segi kedisiplinan maupun pencapaian target kinerja.

d. Peneliti selanjutnya Agar memperoleh hasil yang lebih baik dalam sebuah penelitian kami mohon untuk peneliti setelah kami ini untuk mengunakan variabel yang lain. Sehingga dapat memenuhi harapan dalam sebuah karya ilmiah (tesis) yang lebih sempurna lagi.

\section{DAFTAR PUSTAKA}

Allwinkle, S. and Cruickshank, P., (2011). Creating smart-er cities: An overview. Journal Of Urban Technology, 18(2), pp.1-16.

Ahmad Husni Hamim, 2015, Aktualisasi Integritas Bagi PNS/ASN, Widyaiswara Adm BDK Bandung. 
Budi Suprapto, 2012, Faktor - Faktor Yang Mempengaruhi Kinerja Pegawai Pada Bagian Hukum dan Kepegawaian Direktorat Jendral Pendidikan Dasar, Tesis di Publikasikan Universitas Indonesia.

Batty, M., Axhausen, K.W., Giannotti, F., Pozdnoukhov, A., Bazzani, A., Wachowicz, M., Ouzounis, G. and Portugali, Y., (2012). Smart cities of the future. The European Physical Journal Special Topics, 214(1), pp.481-518.

Caragliu, A., Del Bo, C. and Nijkamp, P., (2011). Smart cities in Europe. Journal of urban technology, 18(2), pp.65-82.

Dutton, W.H., Kraemer, K.L. and Blumler, J.G., (1987). Wired cities: Shaping the future of communications. Macmillan Publishing Co., Inc..

Dwi Aryani, Febrina Rosita, 2010, Pengaruh Kwalitas Layanan Terhadap Kepuasan Pelanggan Dalam Membentuk Loyalitas Pelanggan, jurnal Ilmu Administrasi dan Organisasi, Vol 17 Hal. 114 - 126.

Ishida, T. and Isbister, K. eds., (2000). Digital cities: technologies, experiences, and future perspectives. Springer Science \& Business Media.

Komninos, N., (2002). Intelligent cities: innovation, knowledge systems, and digital spaces. Taylor \& Francis.

Linda Aryani dkk, 2013, Kompetensi Tidak Sempurna Tanpa Integritas Pada Pimpinan, Jurnal ilmiah Psikologi,Vol 9.

Lubis,2008, Pengaruh Pelatihan dan Motivasi Kerja Terhadap kinerja Karyawan PT Perkebunan Nusantara IV (Persero) Medan

Marius R, 2010, Hubungan Antara Kemampuan Manajerial Kepala sekolah, Motivasi Guru, Lingkungan Kerja dan komitmen Guru dengan Kinerja Guru SMP di Kabupaten Bantul, Jurnal Manajemen

T.Ivana Elitasari, 2014, Pengaruh Kepemimpinan Transformasional Dan Motivasi Berprestasi Terhadap Kinerja, Tesis dipublikasikan Universitas Gajahmada Jogyakarta

Yulianti, Wuryanti, 2015, Pengaruh Kepemimpinan Transformasional, Integritas Perilaku, Dan kepercayaan Terhadap Pimpinan Dalam Peningkatan Kinerja SDM ( Studi BLHP, BKPPD dan BPMP Kabupaten Konawe Selatan Provinsi Sulawesi Tenggara), Jurnal MSDM, Vol 2 hal $281-300$ 